\title{
DESCRIPTION OF A NEW CRUSTACEAN OF THE GENUS SPHAROMA FROM A WARM SPRING IN NEW MEXICO.
}

By Harriet Richardson.

A NUMBER of specimens of the following species were collected by Mr. Theodore D. A. Cockerell, a few miles west of Socorro, New Mexico, where they were found living in a warm spring. The only other instance of a fresh-water Sphcroma is that of $S$. dugesi, a Mexican species, described by Adrien Dollfus. ${ }^{1}$ The differences between his species and the present one will appear in the description.

\section{SPHÆROMA THERMOPHILUM, new species.}

Head nearly three times as broad as long, with its anterior margin widely rounded. Eyes round and post-laterally situated. The first pair of antennæ, with a flagellum of eight articles, extends to the middle of the first thoracic segment. The second pair of antennæ reach the posterior margin of the first thoracic segment; the flagellum contains eleven articles.

The thoracic segments are all similar with the exception of the first, which extends laterally around the head, almost touching the peduncle of the first pair of antennæ with its anterior angle. The epimeral parts are continuous with the segments with no indication of a separation from them.

The abdomen is formed of two distinct segments, the first of which is partly covered by the last thoracic segment, the second is sub-triangular, rounded posteriorly. The internal lamella of the uropods is moderately broad, well rounded, and extends to the posterior edge of the last abdominal segment. The external lamella is half as long and half as broad as the internal one, and is more pointed at its extremity.

The body is oblong-ovate with almost parallel sides. Its surface is entirely smooth.

The grayish-brown color of the body is everywhere markerl with small black spots and lines, which run together, forming a broad, black band

${ }^{1}$ Bull. Soc. Zool. France, 1893, XVIII, p. 115, figs. 1, 2.

[Advance sheet of this paper was published February 6, 1897.]

Proceedings U. S. National Museum, Vol. XX-No. 1128.

Proc. N. M. vol. $\mathrm{xx}-30$ 
in the center of each one of the thoracic segments. All the exposed edges of the body are tinged with a bright orange.

This species can readily be distinguished from $S$. dugesi, to which it is closely related, by the absence of hairs on the body, by the relative length of the uropods, the outer one being only half as long as the inner one, while in S. dugesi they are of equal length, and by the difference in color.

Type.-No. 19609, U.S.N.M. 
PRELIMINARY DIAGNOSES OF NEW MAMMALS OF THE GENERA MEPHITIS, DORCELAPHUS, AND DICOTYLES, FROM THE MEXICAN BORDER OF THE UNITED STATES.

By Edgar A. Mearns, M. D., Assistant Surgeon, United States Army.

THIS Is the sixth of a series of papers giving preliminary descriptions of the new mammals collected on the recent survey of the boundary between Mexico and the United States. ${ }^{1}$ Detailed descriptions, with illustrations of the new forms, and comparisons with their allies will appear later, in the report on the collections made by the International Boundary Commission.

MEPHITIS MILLERI, new species.

MILLER'S HOODED SKUNK.

Type.-No.58851, U.S.N.M. (Collection International Boundary Commission). Skin and skull. Adult male, from Fort Lowell (near Tucson), Arizona. Collected by Mr. F. X. Holzner, November 13, 1893. Original number, 1109.

Description of type.--In winter pelage. Body slender. Caudal vertebræ longer than head and body. Nape with a hood of spreading elongated hair. Coat long and glossy, with copious fine underfur. Head with a narrow, longitudinal, white stripe above. Color glossy black, with a white area low lown on the sides, extending from the ear to the tail, and tending to form a double stripe toward either extremity. Tail all white at base of hair; externally black above and all round subtermin ally; under side all white, except the subterminal black ring. End of tail with a copious tuft of white hair nearly $300 \mathrm{~mm}$. in length. Feet and under parts, except tail, all black. Length to end caudal vertebræ, $790 \mathrm{~mm}$.; tail to end of vertebræ, 435; ear from crown, 18; length of hind foot, 73 .

${ }^{1}$ Proc. U.S. Nat. Mus., XVII, 1894, pp. 129-130; XVIII, 1895, pp. 443-447, 551-565; XIX, 1896, p1. 137-140; XX, pp. 457-461.

[Adrance sheets of this paper were published February 11, 1897] 
Another specimen, No. $\frac{207}{3} \frac{7}{9} \frac{2}{3}$, U.S.N.M., male, from the eastern base of the Patagonia Mountains, in the Santa Cruz Valley, near monument No.112, Mexican boundary line, taken November 18,1892 , by Mr. F. X. Holzuer. Original number, s:2, represents a very different but common phase of coloration in this skunk, and in M. macroura Lichten. stein. The upper surface is white, from the occiput to the middle of the back, and the rest of the dorsum, including the whole upper side of the tail, grayish black, beautıfully veiled by long white hairs. In this specimen the white stripe on the upper side of the head is reduced to a trace, and in a few others it is wholly absent. The under surface, including the middle of the tail to near its extremity, is all black, except a white patch rumning backward from the neck to near the middle of the abdomen. There is no white striping low down on the sides. Some specimens have the light back, also the white side-stripes; others have the white dorsal area ending at the lumbar region, with or without white on the sides; and still other individuals are almost wholly black, even as to the tail except at the base of the hair. The two individuals particularly described above are of the common patterns. The species is variable.

The skull, although much larger and relatively narrow zygomatically, is closely similar to that of Mephitis macroura Lichtenstein, of which this may prove to be a subspecies. Named in honor of Mr. Gerrit S. Miller, jr.

\section{DORCELAPHUS CROOKI, new species.}

\section{CROOK'S BLACK-TAILED DEER.}

Type.-No. $\frac{205}{3} \frac{5}{7} \frac{7}{2} \frac{2}{2}$, U.S.N.M. (Collection International Boundary Commission). Adult female; shot by the author on the summit of the Dog Mountains, Grant County, New Mexico, June 9, 1892. Original number, 1873.

Description of type.-In the summer pelage. Color reddish fawn, darker from black annulations on the back, lightening to grayish cinna. mon on the sides, and grayish drab on the neck. The legs are creambuff, except where new clay colored hair is coming in on the anterior border, the limbs being almost the last part to receive the summer coating. The coloring of the head is very similar to that of the mule deer in corresponding pelage. It has the horseshoe or arrow mark on the forehead, and other dark markings of the head to correspond; and the ears are relatively almost or quite as large, and as scantily coated with hair. The bushy hair around the metatarsal gland, which agrees in size and location with that of Dorcelaphus columbianus, is sooty at base, and white apically. The tail is colored much as in D. columbianus, but has a longer terminal switch; upper side and extremity of tail all black, lower side white mesially, and naked towards the base. The pelage of this deer is short and coarse in comparison with that of the white-tailed or Virginia deer, or the black-tailed deer of the Columbia River region; 
and, as would naturally be expected, is not so red as that of the latter. This specimen contained a fotus the size of a cottontail rabbit. The measurements of the type, taken from the fresh specimen, are as follows: Total length, measured in a straight line, $1,440 \mathrm{mp}$.; tail vertebræ, 195 (to end of hairs, 304); ear above crown, 220; ear above notch, 190; width following curve, 125; distance between eyes, 100 ; girth of chest, 790; distance from head of humerus to head of femur, 620 ; from tip of nose to eye, 155 ; to center of pupil, 175 ; to base of ear. 290 ; to tip of ear, 470 ; to occiput, 295 ; height of animal at shoulder, 650 ; fore limb from coracoid, 630; from olecranon, 540; length of manus, 300 ; hind limb from knee-joint, 620 ; length of pes, 400 . Weight, evicerated and dry, 72 pounds avoirdupois.

Cranial characters.-The skull has very nearly the same conformation as that of $D$. columbianus, the lachrymal fossa being deeper than in the Virginia deer, but shallower than in the mule deer. The same intermediate condition obtains with respect to the vomer, in the relationships of the nasal and premaxillary bones, in the form and size of the teeth; and, in short, the whole animal appears to be a compromise between the characteristics of the white tailed and mule deer. Named in honor of Major-General George Crook, United States Army.

DICOTYLES ANGULATUS SONORIENSIS, new subspecies.

\section{YAQUI PECCARY.}

Type.-No. $\frac{20657}{35814}$, U.S.N.M. (Collection International Boundary Commission). Adult male, from San Bernardino River, Sonora, Mexico, near monument No. 77, Mexican boundary line. Collected by Doctor Elgar A. Mearns and Mr. F. X. Holzner, September 8, 1892. Original number, 2099.

Description of type.-Above, there is a mane of long, black-tipped bristles, extending from the crown to the naked gland on the rump, the longest bristle measuring $135 \mathrm{~mm}$. in length. The rest of the upper surface is a pepper-and-salt mixture of commingled grayish-white, yellowish-white, and brownish-black colors, the bristles being whitish, ringed and pointed with black. The flanks are whitest and the shoulders blackest. An incomplete and rather indistinct whitish collar extends across the side, behind the neck, and in front of the shoulder. The muzzle, cheeks, and space in front of the eye are brownish gray, annulated with darker. There is a brownish-white orbital area, and a brownish glandular stain below the front of the eye. The under jaw is yellowish, with a triangular blackish patch near the end of the chin. The ears have their outer surface and tip of inner surface coated with black bristles; concavity rugose, with five bands of long, buffy-white hairs occupying the ridges. Legs mixed brownish white and brownish black, becoming solidly black about the hoofs, and with a light band encircling the fore leg above the accessory hoofs. Under surface of 


\section{$2 \mathrm{BHL}$ Biodiversity Heritage Library}

Mearns, Edgar Alexander. 1897. "Preliminary diagnoses of new mammals of the genera Mephitis, Dorcelaphus, and Dicotyles, from the Mexican border of the United States." Proceedings of the United States National Museum 20(1129), 467-471. https://doi.org/10.5479/si.00963801.1129.467.

View This Item Online: $\underline{\text { https://www.biodiversitylibrary.org/item/53812 }}$

DOI: https://doi.org/10.5479/si.00963801.1129.467

Permalink: https://www.biodiversitylibrary.org/partpdf/53244

\section{Holding Institution}

Smithsonian Libraries

\section{Sponsored by}

Smithsonian

\section{Copyright \& Reuse}

Copyright Status: Public domain. The BHL considers that this work is no longer under copyright protection.

This document was created from content at the Biodiversity Heritage Library, the world's largest open access digital library for biodiversity literature and archives. Visit BHL at https://www.biodiversitylibrary.org. 